\section{Allenby, Field Marshal Edmund (1861-1936)}

JEAN BOU

Field Marshal Edmund Allenby was a British army officer and later colonial administrator who successfully commanded the Egyptian Expeditionary Force (EEF) against the Ottoman armies in Palestine in 1917-1918.

The second child of a country squire, Allenby attended a public school and twice failed the Indian Civil Service examination before successfully sitting the entrance examination for the Royal Military Academy at Sandhurst in 1880. Upon graduation in 1882 he sailed to South Africa to join the 6th (Inniskilling) Dragoons. Allenby spent the rest of the decade leading the agreeable and professionally useful life of a junior cavalry officer on colonial duty in Natal. Following the Inniskilling's return to Britain in 1890, Allenby passed the entrance examination to the Staff College at Camberley on his second attempt in 1895. The first cavalry officer to gain entrance by examination, he graduated in the top third of the class.

Allenby then served in Ireland before returning to his regiment as it sailed for the Second Anglo-Boer War in late 1899. He was soon made a squadron commander and established his status as a capable officer in the operations against the Boer republics in 1900 . He was made temporary commander of his regiment in mid-1900 and as the war changed from its conventional phase into a guerilla war was given command of one of the columns that took to sweeping the veld. Allenby further enhanced his reputation as he successfully commanded his force, almost without respite, until the end of the war in 1902.

With peace came a return to England and command of the 5th Royal Irish Lancers and then the 4th Cavalry Brigade. By 1910 he was a major general and inspector general of cavalry.

With Britain's entry into World War I in August 1914, Allenby went to France and commanded the Cavalry Division, where his performance was mixed during the retreat from Mons. His oversized division (four brigades when three were found the cavalry optimum) had rarely trained as such and was quickly in action, where the inexperience of his staff and problems of communication over broad frontages during mobile operations were soon apparent. Allenby had an uneasy relationship with several of his senior officers and one brigade commander, Brigadier General Hubert Gough, effectively removed his formation from the division by marching it off to another corps in which his brother was the chief of staff. If open to criticism, Allenby's performance was not disastrous and his division adequately covered the British Expeditionary Force's (BEF) difficult and dangerous retreat.

As the BEF expanded, Allenby successively commanded the Cavalry Corps, V Corps and then, from October 1915, Third Army. His command of these formations was not distinguished, nor was it contemptible. At the First Battle of Ypres in October-November 1914, the Cavalry Corps and Allenby played a significant part in the defensive fighting. Similarly, his Third Army had notable successes in the opening attacks of the Battle of Arras in April 1917. Allenby, whose planning for the offensive had been sometimes innovative and always thorough, received the plaudits, but his reputation suffered as the offensive bogged down and casualties increased. He insisted on continuing with costly attacks when the opportunities for success had slipped away, and his previous thoroughness gave way to what seemed like bloody mindedness. His tense and awkward relationship with the BEF's commander, 
Field Marshal Sir Douglas Haig (which dated back to staff college), deteriorated and three of Allenby's somewhat browbeaten divisional commanders took the extraordinary step of writing to him to make clear their objections to further attacks. Soon afterward London was looking for a new commander in Palestine to replace the unimpressive General Sir Archibald Murray, and when Allenby's name was suggested Haig made no effort to retain him.

Personally amiable as a junior officer, Allenby had nevertheless shown a martinet's streak which became more obvious as he attained senior ranks. Nicknamed "the Bull," he was prone to terseness, explosive outbursts, and what sometimes appeared to be an overzealous dedication to eradicating pet hates. This professional character was in marked contrast to his private one, and upon closer acquaintance people were often surprised to find him personable, erudite, and fond of children. His bullishness was likely a reflection of an underdeveloped senior command style, the need to execute sometimes unpopular decisions in a small pre-war army, and perhaps an underlying personal shyness. It made him often unpopular with subordinates of all ranks and had contributed to the command problems he had experienced during the retreat of 1914 and at Arras.

Allenby initially thought the transfer to Palestine a mark of failure, but he seemed to be transformed by a theater where he was the commander in chief and which offered much more operational latitude. Though he always maintained a reputation for an explosive temper, here, partly by comparison with his predecessor, he was viewed as competent, fair, energetic, and open minded. He now gained loyalty and admiration from his subordinates, though there were those in France who had felt the same.
The impression is that, for the first time, in Palestine he was able to relax into his senior rank and appointment. Soon after his arrival in the Middle East came the news that his only child, Michael, had been killed on the Western Front while serving as an artillery subaltern. He mostly concealed the grief from his fellow officers and what affect, if any, this loss had on Allenby's outlook and style can only be guessed at.

After reinvigorating the EEF, and greatly helped by the extra resources sent by London, Allenby broke the Ottoman Army in southern Palestine in October-November 1917. Though the enemy eluded his attempted envelopment, he pursued it into central Palestine, seizing Jerusalem in early December. After the winter he consolidated his line, but major operations were forestalled by the German offensives on the Western Front in March 1918, which required sending large reinforcements to France. Allenby made two forays across the Jordan River in March and April, which were both defeated by the Ottoman army and rank as the major misjudgments of his campaign. Reinforced by Indian troops over the summer he again undertook a major offensive in September 1918. An infantry and artillery breakthrough along the Mediterranean coast was followed by a corps-sized cavalry exploitation into the enemy's rear and a subsidiary strike across the Jordan. Three Ottoman armies were destroyed and the EEF pushed on to capture Damascus. It had advanced as far as Aleppo on the Anatolian frontier when the Ottoman Empire was granted an armistice on October 30. The Battle of Megiddo, as it became known, and the subsequent advances, were among the most remarkable operations undertaken by the British imperial armies during the war and are often regarded as pointers to the all-arms maneuver battles of 
World War II. Throughout the campaign Allenby fostered the Arab Revolt as an adjunct to the EEF.

In 1919 Allenby was made Viscount Allenby of Megiddo and Felixstowe, and a field marshal. As the high commissioner to Egypt (1919-1925) he asserted British control after the Egyptian Uprising and played a role in that country's attainment of independence in the early 1920s. He was later rector of the University of Edinburgh. Personally brave and seemingly imperturbable in battle, he was also well read, religious and held diverse non-military interests, particularly in botany, music, ornithology, and travel.
SEE ALSO: Anglo-Boer Wars (1880-1881, 1899-1902); Liman von Sanders, General Otto Karl Victor (1855-1929); Lloyd George, David (1st Earl Lloyd George) (1863-1945); World War I: Afro-Asian theaters.

\section{FURTHER READING}

Gardiner, B. (1966) Allenby. London: Cassell.

Hughes, M. (1999) Allenby and British Strategy in the Middle East, 1917-1919. London: Frank Cass.

Lawrence, J. (1993) Imperial Warrior: The Life and Times of Field-Marshal Viscount Allenby, 1861-1936. London: Weidenfeld and Nicolson.

Wavell, A. (1940) Allenby: A Study in Greatness. London: George G. Harrap. 